УДК 339.9: 330.131.7

DOI: https://doi.org/10.37320/2415-3583/11.4

Дергачова B.B.

доктор економічних наук, професор, завідувач кафедри менеджменту, Національний технічний університет Украӥни «Київський політехнічний інститут імені Ігоря Сікорського» ORCID: https://orcid.org/0000-0003-0317-8675

Манаснко I.М.

кандидат економічних наук, доцент кафедри менеджменту, Начіональний технічний університет Украӥни «Київський політехнічний інститут імені Ігоря Сікорського» ORCID: https://orcid.org/0000-0002-3246-3603

\title{
РИЗИКОЛОГІЯ: УПРАВЛІННЯ, ПРОЕКТИ, ТРЕНДИ ТА ПЕРСПЕКТИВИ
}

\begin{abstract}
Дослідження присвячене розгляду теоретичних засад управління ризиками, з одного боку, а з іншого - аналізу країн - глобальних лідерів світової економіки з урахуванням ризиків їх функціонування. Визначено, шчо в ризикології особливе місие посідає управління проєктним ризиками. Обірунтовано, що географічна локачія є визначальним чинником у системі управління ризиками. Представлено аналіз глобальних ризиків світової економіки, які $\epsilon$ не керованими, але здійснюють суттєвий вплив на суб'єктів бізнесу. Наведено перелік ризиків, притаманних країнам, які посідають лідируючи позииї за певними показниками. Такими показниками визначено обсяг ВВП за ПКС, ВВП на душу населення. А також визначено краӥн-лідерів за рейтингом економічної свободи, обсягом витрат на НДДКР тощэ. Визначено, щзо країни функиіонують в умовах таких ризиків (притаманних окремим країнам, а не всім лідерам), як ресурсна чи фінансова залежність, демографічне навантаження, недиверсифікованість економіки, залежність від імпортної робочої сили тощо. А до глобальних ризиків віднесено такі: цінові економічні бульбашки, незаконна торгівля, некерована інфлячія, зміни иін на енергоресурси. Обтрунтовано, щуо зазначені глобальні ризики мають бути враховані у системі управління проєктними ризиками відповідних суб'єктів бізнесу.
\end{abstract}

Ключові слова: ВВП, економіка, економічна свобода, лідерство, рейтинги, ризики, НДДКР, проєкти, стратегії, управління.

Постановка проблеми. Тренди розвитку світової економіки сьогодення є досить турбулентними, що викликано невизначеністю як у межах однієї країни, так і регіональних чи корпоративних утворень. Нині кожна країна та суб'єкт бізнесу незалежно від географічної приналежності функціонує в умовах невизначеності. Будь-який суб'єкт бізнесу тією чи іншою мірою стикається 3 ризиками незалежно від того, яку продукцію виробляє й які послуги надає. Прискорення темпів змін у зовнішньому і внутрішньому середовищі певної країни/регіону/підприємства призводить до виникнення значної кількості складних ризиків, які мають істотний вплив на організацію. Відповідно, ефективність діяльності суб' єктів бізнесу багато в чому стає залежною від чинників, що $\epsilon$ причиною невизначеності в умовах нерівноважної економіки (нові технології, зростаюча глобальна конкуренція, зміна організаційних структур у результаті скорочень, реінжинірингу і злиттів тощо). Низка чинників, у тому числі неекономічного характеру, стимулює значні перетворення, а також створює ризиковану атмосферу бізнесу. Це, своєю чергою, стимулює необхідність використання більш досконалих підходів до управління ризиками, що дають змогу значно підвищувати конкурентоспроможність суб'єктів бізнесу. Водночас украй важливим для суб'єктів бізнесу $є$ їх географічна приналежність, оскільки в одних країнах $\epsilon$ розвинена система ризик-менеджменту на державному рівні, а в інших навіть нестабільність державної політики вже $є$ джерелом ризику для суб' єктів бізнесу.

У цілому розвиток світової економіки супроводжується постійними змінами, економічно-соціальними пріоритетами функціонування окремих впливових країн. Тренди та моделі розвитку світової економіки систематично виводять одних країн на лідерські позиції, інших - в аутсайдери. При цьому аутсайдерами виявляються ті, хто не в змозі справлятися з ризиками різного характеру, які можуть носити не лише економічний характер (наприклад, бути спровокованими фінансовою залежністю), а й ризик стихійних лих великого масштабу, інфекційних захворювань тощо. При цьому ризикові ситуації підривають питання національної безпеки країн, тому актуальним є дослідження країн та груп країн, які є глобальними лідерами на світовому ринку, з урахуванням ризиків, що їх супроводжують.

Аналіз останніх досліджень і публікацій. Серед дослідників-теоретиків, які зробили сут- 
тєвий внесок у розвиток теорії ризику, можна виділити таких учених, як Дж.М. Кейнс, А. Маршалл, О. Моргенштейн, Ф. Найт, Дж. Нейман, Б.А. Райзберг. Ранжування країн для визначення світових лідерів за певним критерієм можна знайти на інформаційних ресурсах МВФ [3], ООН [4], Групи Світового банку [5], Central Intelligence Agency США [6]. Водночас міжнародні рейтингові та інформаційні агентства здійснюють дослідження щодо визначення країн-лідерів за певними напрямами діяльності. Наприклад, The Heritage Foundation [10] здійснюють ранжування країн за показником економічної свободи. Інформаційний pecypc howmuch.net [12] представляє інфографічні дані щодо обсягів фінансування НДДКР та публікує рейтинг відповідних країнлідерів. Незважаючи на позиції країни у світових рейтингах, усі країни функціонують в умовах глобальних ризиків. У цьому аспекті доречно відзначити публікації World Economic Forum [1] та The Economist Intelligence Unit [9]. Тож доречним $є$ подальші дослідження щодо обгрунтування країн - лідерів світової економіки з урахуванням глобальних ризиків.

Мета статті полягає у виявленні та обгрунтуванні країн - лідерів світової економіки в умовах ризикології на основі макроекономічних показників їхньої діяльності та міжнародних рейтингів, беручи до уваги теоретичні засади управління ризиками.

Для досягнення визначеної мети використано систему загальнонаукових та спеціальних методів, а саме: методи системно-функціональ- ного підходу до поглиблення теми дослідження; методи систематизації, групування та узагальнення, формалізації з метою формування та представлення аналітичних показників розвитку країн світу, їх місця у світовій економіці; методи індукції та дедукції, наукової абстракції; методи структурно-логічного та семантичного аналізу - для виявлення основних ризиків країн-лідерів тощо.

Виклад основного матеріалу. Ризик - зворотний бік свободи підприємництва, ризик - це й $є$ необхідність самостійного прийняття рішення в умовах невизначеності, коли передбачити наслідки прийнятого рішення практично неможливо. Ризик - імовірнісна подія, яка в разі виникнення може спричинити загрозу втрати частини своїх ресурсів, недоотримання доходів або появи додаткових витрат i/або можливість отримання значної вигоди (доходу) в результаті здійснення підприємницької діяльності в умовах невизначеності. Тому сутнісна характеристика ризику може мати i позитивний ефект на діяльність підприємства/країни/регіону. Сучасне розуміння ризикменеджменту базується на так званій «концепції прийнятного ризику», згідно 3 якою основною метою процесу управління ризиком $є$ надання максимальної стійкості всіх видів діяльності суб'єкту бізнесу шляхом утримання сукупного ризику (очікуваного рівня втрат) у допустимих стратегією межах розвитку компанії.

Особливе значення у вирішенні даного завдання набувають інструменти і методи управління ризиками, які не тільки дають можливість

Таблиця 1 - Глобальні економічні ризики

\begin{tabular}{|l|l|}
\hline \multicolumn{1}{|c|}{ Глобальні ризики } & \multicolumn{1}{c|}{ Опис ризиків } \\
\hline Цінові економічні бульбашки & $\begin{array}{l}\text { Завищена вартість на активи, такі як товари, житло, акції тощо, } \\
\text { в економіці потужної країни чи регіоні }\end{array}$ \\
\hline Дефляція & Тривала майже нульова інфляція або дефляція в економіці країни \\
\hline $\begin{array}{l}\text { Невдача великого фінансового } \\
\text { механізму або установи }\end{array}$ & $\begin{array}{l}\text { Зрив фінансової установи та/або несправність у роботі фінансової } \\
\text { системи, яка впливає на глобальну економіку }\end{array}$ \\
\hline Збій критичної інфраструктури & $\begin{array}{l}\text { Недостатньо інвестувати, модернізувати та/або забезпечувати безпеку } \\
\text { інфраструктурних мереж (наприклад, енергетику, транспорт і зв'язок), } \\
\text { що призводить до тиску або поломки із загальносистемними наслідками }\end{array}$ \\
\hline $\begin{array}{l}\text { Основні фінансові кризи } \\
\text { економіки }\end{array}$ & $\begin{array}{l}\text { Надмірне навантаження на борги, які породжують кризи суверенного } \\
\text { боргу та/або кризи ліквідності }\end{array}$ \\
\hline $\begin{array}{l}\text { Високе структурне безробіття } \\
\text { або неповна зайнятість }\end{array}$ & $\begin{array}{l}\text { Стійкий високий рівень безробіття або неповне використання } \\
\text { виробничої спроможності зайнятого населення }\end{array}$ \\
\hline $\begin{array}{l}\text { Незаконна торгівля (наприклад, } \\
\text { незаконні фінансові потоки, } \\
\text { ухилення від сплати податків, } \\
\text { торгівля людьми, організована } \\
\text { злочинність тощо) }\end{array}$ & $\begin{array}{l}\text { Масштабні заходи поза законодавчою базою, такі як незаконні } \\
\text { фінансові потоки, ухилення від сплати податків, торгівля людьми, } \\
\text { підробка та/або організована злочинність, які деструктують соціальну } \\
\text { взаємодію, регіональну чи міжнародну співпрацю та глобальний ріст }\end{array}$ \\
\hline $\begin{array}{l}\text { Сценарний шок цін на енергію } \\
\text { (збільшення або зменшення) }\end{array}$ & $\begin{array}{l}\text { Значне зростання або зменшення цін на енергоресурси спричиняє } \\
\text { подальший економічний тиск на енергозалежні галузі та споживачів }\end{array}$ \\
\hline Некерована інфляція & $\begin{array}{l}\text { Некероване зростання загальних рівнів цін на товари та послуги в } \\
\text { ключових економіках }\end{array}$ \\
\hline
\end{tabular}

Дюерело: [1] 
мінімізувати ризикованість діяльності, а й дають змогу привести у відповідність внутрішній потенціал суб'єкта бізнесу 3 умовами зовнішнього середовища, а також розвивати його в довгостроковій перспективі в умовах жорсткої конкурентної боротьби. При цьому особлива увага повинна бути спрямована на вивчення закономірностей формування нового підходу до процесу управління ризиками суб'єкта бізнесу, що передбачає комплексний розгляд ризиків усіх підрозділів і напрямів діяльності, що вимагає ретельного вивчення особливостей i виділення основних напрямів модифікації процесу управління ризиками.

Особливо важливу роль управління ризиками відіграє під час управління проєктами (як конкретного суб'єкта бізнесу, так і держави у цілому). Велика кількість учасників і зацікавлених сторін проєкту також може бути джерелом виникнення безлічі ризиків. Технічна, організаційна та фінансова складність сучасних проєктів також вносить свою лепту в проблему управління проєктними ризиками, тому воно має базуватися на використанні комплексу методів мінімізації ризиків та поєднанні стандартних методів (хеджування, попередження, диверсифікація тощо) із новими міждисциплінарними підходами до управління проєктними ризиками. Традиційний перелік методів та інструментів управління проєктними ризиками має бути доповнено методами, що дають змогу істотно підвищити ефективність управління ризиками проєкту, зокрема: методи активізації творчого потенціалу і підвищення узгодженості дій учасників проекту, метод Дельфі, метод синектики, метод розроблення сценаріїв, метод морфологічного аналізу, метод ділових ігор, використання карти ризиків тощо.

Проте є низка ризиків, якими суб'єкт бізнесу не в змозі управляти на рівні окремих проектів, - це глобальні ризики, які мають бути враховані в діяльності суб'єкта бізнесу/країни/регіону. Поняття «глобальний ризик» є основоположним для стратегування багатьох країн. Відповідно до трактувань Всесвітнього економічного форуму, «глобальний ризик» визначається як невизначена подія або умова, яка, якщо вона настане, може спричинити значний негативний вплив для кількох країн або галузей протягом наступних 10 років [1]. У дослідженнях Всесвітнього економічного форуму наведено основні глобальні ризики світової економіки (табл. 1).

Звичайно, ці ризики матимуть вплив на більшість країн світу незалежно від їх структури еко-

Таблиця 2 - Країни 3 найвищим ВВП на душу населення, дол. США

\begin{tabular}{|c|l|l|l|l|l|l|}
\hline \multirow{2}{*}{ Місце } & \multicolumn{2}{|c|}{$\mathbf{2 0 0 8}$ р. } & \multicolumn{2}{c|}{ 2014 p. } & \multicolumn{2}{c|}{ 2019 p. } \\
\cline { 2 - 7 } & \multicolumn{1}{|c|}{ Країни } & ВВП на д.н. & \multicolumn{1}{c|}{ Країни } & ВВП на д.н. & Країни & ВВП на д.н. \\
\hline 1 & Катар & 102,1 & Монако & 171,5 & Люксмбург & 113,2 \\
\hline 2 & Ліхтенштейн & 89,4 & Катар & 139,8 & Швейцарія & 83,7 \\
\hline 3 & Бермуди & 86,0 & Ліхтенштейн & 115,6 & Макао & 81,8 \\
\hline 4 & Люксембург & 77,9 & Кувейт & 82,2 & Норвегія & 77,9 \\
\hline 5 & Монако & 65,5 & Сінгапур & 80,3 & Ірландія & 77,7 \\
\hline 6 & Сінгапур & 62,4 & Люксембург & 79,0 & Катар & 69,6 \\
\hline 7 & Норвегія & 55,4 & Бруней & 72,2 & Ісландія & 67,0 \\
\hline 8 & Бруней & 54,8 & Бермуди & 66,5 & США & 65,1 \\
\hline 9 & США & 52,8 & ОАЕ & 66,3 & Сінгапур & 63,9 \\
\hline 10 & ОАЕ & 49,0 & Норвегія & 65,9 & Данія & 59,7 \\
\hline
\end{tabular}

Джерело: складено авторами на основі джерела [6]

Таблиця 3 - Рейтинг країн світу за ВВП (за ПКС), млрд дол.

\begin{tabular}{|c|l|l|l|l|l|l|}
\hline Місце & \multicolumn{3}{|c|}{2006 рік } & \multicolumn{2}{c|}{ 2012 рік } & \multicolumn{2}{c|}{ 2018 рік } \\
\hline 1 & СС & 13080,0 & СС & 15700,0 & Китай & 25362 \\
\hline 2 & США & 13060,0 & США & 15670,0 & СС & 22734 \\
\hline 3 & Китай & 10210,0 & Китай & 12380,0 & США & 20494 \\
\hline 4 & Японія & 4218,0 & Індія & 4735,0 & Індія & 10498 \\
\hline 5 & Індія & 4164,0 & Японія & 4617,0 & Японія & 5485 \\
\hline 6 & Німеччина & 2632,0 & Німеччина & 3194,0 & Німеччина & 4505 \\
\hline 7 & Великобританія & 1928,0 & Росія & 2509,0 & Росія & 3986 \\
\hline 8 & Франція & 1902,0 & Бразилія & 2362,0 & Бразилія & 3366 \\
\hline 9 & Італія & 1756,0 & Великобританія & 2323,0 & Великобританія & 3074 \\
\hline 10 & Росія & 1746,0 & Франція & 2253,0 & Франція & 3073 \\
\hline
\end{tabular}

Джерело: складено авторами на основі джерела [6] 


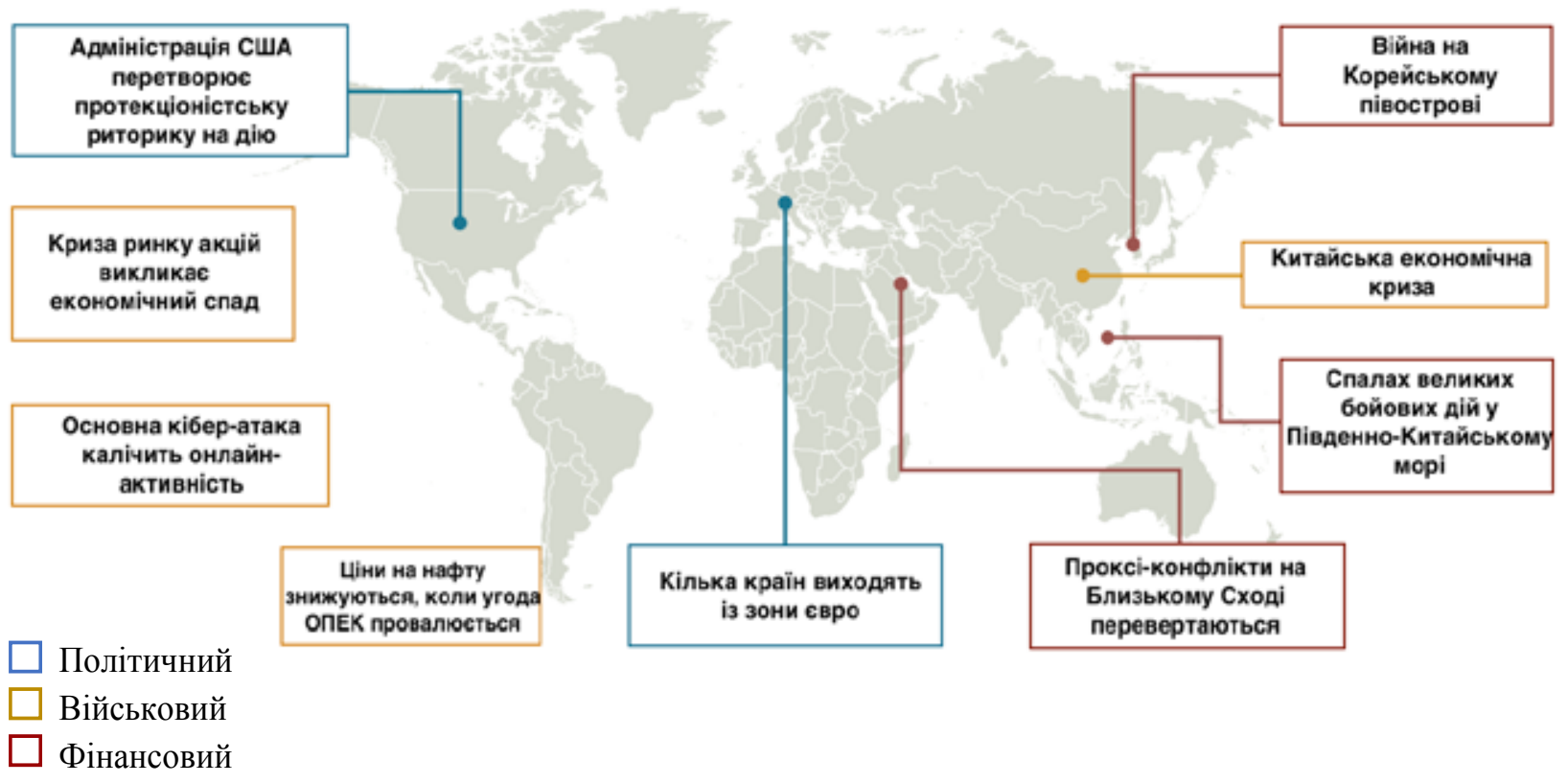

Рисунок 1 - Глобальні сценарії ризику [9]

Таблиця 4 - Топ-10 глобальних ризиків за ступенем інтенсивності

\begin{tabular}{|l|l|l|}
\hline Категорія & Інтенсивність & \multicolumn{1}{c|}{ Сценарій } \\
\hline 1 & 15 & Тривале падіння основних фондових ринків дестабілізує світову економіку \\
\hline 1 & 15 & Світова торгівля падає, коли США посилюють протекціоністську політику \\
\hline 2 & 12 & $\begin{array}{l}\text { Територіальні суперечки в Південно-Китайському морі призводять до спалаху } \\
\text { бойових дій }\end{array}$ \\
\hline 2 & 12 & Світовий темп зростання майже 4\% \\
\hline 3 & 12 & Кібератаки підривають корпоративну та державну діяльність \\
\hline 3 & 10 & Китай зазнає невпорядкованого та тривалого економічного спаду \\
\hline 4 & 10 & На Корейському півострові відбувається велике військове протистояння \\
\hline 5 & 10 & $\begin{array}{l}\text { Проксі-конфлікти на Близькому Сході переростають у прямі протистояння, } \\
\text { які деструктують глобальні енергетичні ринки }\end{array}$ \\
\hline
\end{tabular}

Джерело: [9]

Таблиця 5 - Рейтинг країн за рівнем економічної свободи, 2019

\begin{tabular}{|l|l||l|l|l|l|}
\hline \multicolumn{2}{|c||}{ Топ-10 лідерів } & \multicolumn{2}{c|}{ Позиції України } & \multicolumn{2}{c|}{ Топ-10 аутсайдерів } \\
\hline $\begin{array}{c}\text { Позиція } \\
\text { в рейтингу }\end{array}$ & $\begin{array}{c}\text { Позиція } \\
\text { вейтингу }\end{array}$ & \multicolumn{1}{|c|}{ Країна } & $\begin{array}{c}\text { Позиція } \\
\text { в рейтингу }\end{array}$ & Країна \\
\hline 1 & Гонконг & 143 & Гаїті & 171 & Алжир \\
\hline 2 & Сінгапур & 144 & Сгипет & 172 & Тимор \\
\hline 3 & 145 & Камерун & 173 & Болівія \\
\hline 4 & Нова Зеландія & 146 & Гамбія & 174 & $\begin{array}{l}\text { Екваторіальна } \\
\text { Гвінея }\end{array}$ \\
\hline 5 & Швейцарія & 147 & Україна & 175 & Зімбабве \\
\hline 6 & Австралія & 148 & Аргентина & 176 & Республіка Конго \\
\hline 7 & Ірландія & 149 & Мікронезія & 177 & Еритрея \\
\hline 8 & Великобританія & 150 & Бразилія & 178 & Куба \\
\hline 9 & Канада & 151 & Нігер & 179 & Венесуела \\
\hline 10 & ОАЕ & 152 & Афганістан & 180 & Північна Корея \\
\hline
\end{tabular}

Джерело: складено авторами на основі [10] 
номіки, темпів росту ВВП тощо. Але міра впливу на країни може різнитися залежно від показників імпортозаміщення, експортоорієнтованості, ресурсної чи фінансової залежності.

Найбільш повне уявлення про архітектуру світової економіки та розподіл на групи країн на засадах типології дають дані універсальних міжнародних організацій, членами яких є більшість країн світу: Організації Об'єднаних Націй, Міжнародного валютного фонду і Світового банку. Оцінка цими організаціями груп країн у міжнародній економіці дещо різниться, оскільки відрізняється кількість країн - членів цих організацій (ООН - 193, МВФ - 189, СБ - 189) [2-5].

Виділення країн - світових лідерів 3 усього списку країн світу можливе за такими ознаками: демографічним та економічним потенціалом, забезпеченістю природними ресурсами, ступенем залежності від зовнішніх ринків тощо. Структура світової економіки достатньо неоднорідна i носить незбалансований характер, що породжує низку ризиків.

У табл. 2 представлено країни, які є світовими лідерами за показником ВВП на душу населення. Це країни 3 високим рівнем життя, але вони не позбавлені ризиків.

До ризиків, що характерні для окремих країн даної групи світових лідерів, можна віднести:

1. Високий ступінь залежності від імпортної робочої сили. Наприклад, за даними Світового банку, в 2016 р. країною 3 найвищим ВВП на душу населення у світі був Катар, населення якого всього 2,7 млн осіб, велика частка яких - мігранти. Частка таких робітників у Люксембурзі - 95,2\%.

2. Недиверсифікованість економіки за рахунок розвитку офшорних зон, податкових гаваней тощо. Люксембург, Макао, Ліхтенштейн - держави 3 крихітною кількістю населення (від 601 тис до 38 тис осіб) і являють собою зони пільгового оподаткування чи розвитку криптовалют.

3. Суттєва залежність від декількох галузей економіки. Наприклад, основу економіки Катару, Кувейту, ОАЕ становить видобуток нафти і газу. Для Катару ця галузь забезпечує понад 55\% ВВП, близько 85\% доходів від експорту і 70\% державних доходів. У Люксембурзі частка сфери послугблизько 90\% ВВП.

4. Високий ступінь ресурсної залежності, особливо енергетичної залежності, що підриває фундамент національної безпеки країн. Такі ризики характерні для Люксембургу, Швейцарії, Данії.

Розрив багатства та бідності у світовій економіці зростає. Наприклад, станом на 2016 р. дохід на душу населення в Сінгапурі був у 217,75 рази вище, ніж у найбіднішій Сомалі.

Виокремити наступну групу країн - світових лідерів доречно, проаналізувавши рейтинг країн за показником ВВП за ПКС (табл. 3).
Як свідчать дані, протягом аналізованого періоду варто виокремити стабільну трійку лідерів: ЄС, США та Китай. Також варто відзначити послаблення позицій Великобританії - iз 7-го місця у 2006 р. на 9-е місце у 2018 р. Крім того, ВВП за ПКС збільшується в абсолютному обсязі: ВВП Китаю та Індії збільшився в 2,5 рази, США та СС - лише у два рази, а Японії - лише в 1,15 рази. Дослідження ризиків даної групи країн - світових лідерів має базуватися на системному підході, оскільки ці країни різні за технологічними укладами, ресурсною забезпеченістю, демографічними показниками. Але, на нашу думку, основними макроекономічними ризиками цих країн $\epsilon$ :

- висока ресурсоємність економіки - для Росії, Бразилії;

- значне демографічне навантаження - для Китаю, Індії; EC.

- суттєва енергетична залежність - для Японії,

Розгляд рейтингів ВВП та ВВП на душу населення дає змогу стверджувати, що наявність ресурсів не $\epsilon$ запорукою ефективного розвитку країни та високого рівня іiї національної безпеки.

Якщо проаналізувати тенденції розвитку найбільших за територією країн світу, то буде очевидним аналогічний висновок. Наприклад, США, Росія, Китай, Бразилія, Індія та СС входять до десятки країн - лідерів за ВВП за ПКС, але при цьому жодна держава не входить до топ-15 країн із найбільшим ВВП на душу населення. Наприклад, за рівнем ВВП на душу населення США посідає 18-е місце, Казахстан - 74-е, Канада-32-е, Китай-102-е, Бразилія-108-е, Індія159-е місце [6]. Тож наявність значних територіальних володінь, природних та трудових ресурсів не гарантує високого рівня життя громадян.

Розглянувши декілька світових рейтингів, очевидно, що США, СС та Китай за кількісними параметрами свого розвитку посідають лідерські позиції у світовій економіці. Водночас якщо виникає нестабільність у цих країнах, то вони стають першоджерелом ризиків для інших країн, оскільки вони мають суттєві зв'язки із більшість країн світу у сфері торгівлі, валютно-фінансових відносин, міграції робочої сили тощо. Ці країни використовують стратегї своїх національних безпек як інструмент гарантування свого світового лідерства. В умовах Четвертої промислової революції, або Індустрії 4.0, відповідні стратегії базуються на системних принципах діджиталізації.

Наприклад, у США Стратегія цифрової модернізації (DoD Digital Modernization Strategy) надає дорожню карту для підтримки реалізації зусиль Національної стратегії оборони за допомогою хмарних технологій, штучного інтелекту, кібербезпеки. Країна витратила понад 46,4 млрд дол. у 2019 фінансовому році на реалізацію страте- 
riï The DoD Digital Modernization Strategy [7]. Ці кошти спрямовані в першу чергу на попередження та мінімізацію ризиків національної безпеки. Крім реалізації широкомасштабних стратегій, актуальним інструментом ризик-менеджменту також $є$ окремі закони та регламенти.

Країни намагаються мінімізувати свої макроекономічні ризики, використовуючи надбання Четвертої технологічної революції. Наприклад, у рамках ЄC реалізується Digital Single Market Strategy [8], яка враховує регіональні особливості країн-членів.

Вимірюючи глобальні ризики для світової економіки, не дивно, що можна побачити багато потенційних проблем, що виникають у найбільших світових економіках світу, тобто які $є$ джерелом ризикових ситуацій світового масштабу. Підрозділ The Economist Intelligence Unit вивчає низку ризиків, географічними джерелами яких є США, Китай та ЄС. Окрім того, існують ризики, які або надходять із менших регіональних гарячих точок, або мають більш глобальний характер (рис. 1).

Інтенсивність ризику вимірюється за 25-бальною шкалою й $є$ результатом імовірності виникнення цього ризику та потенційного впливу, який він матиме на глобальну економіку (табл. 4).

Імовірність та вплив кожного ризику класифіковані відповідно до таких категорій:

1. Ймовірність: дуже високий ризик = більше ніж 40\% - ймовірність, що сценарій відбудеться протягом наступних двох років; високий $=$ $31-40 \%$; помірний $=21-30 \%$; низький $=11-20 \%$; дуже низький $=0-10 \%$.

2. Вплив: дуже високий вплив = зміна світового річного ВВП порівняно з базовим прогнозом на $2 \%$ або більше (збільшення ВВП за позитивним сценарієм, зменшення - за негативними сценарієм); високий $=1-1,9 \%$; помірний $=0,5-0,9 \%$; низький $=0,2-0,5 \%$; дуже низький $=0-0,1 \%$.

Із перелічених ризиків (табл. 4) не всі мають негативне значення. Наприклад, світовий темп зростання сягне майже $4 \%$ - це ймовірність позитивного сценарію розвитку світової економіки. Якщо даний показник досліджувати на основі зростання реального ВВП, то в 2017 р. його зростання становило $3,7 \%$. Більшість країн - світових лідерів демонструє незначне економічне зростання (Японія - $1,7 \%, \mathrm{CC}-2,3 \%$, США - 2,2\%), виняток становить Китай - 6,9\% [6].

Найбільш показовим критерієм для співставлення економік країн та аналізу їх місця у структурі світової економіки як країн-лідерів $є$ різноманітні рейтинги, де країни градуйовані за певними параметрами та показниками.

Про високий ступінь стабільності країн, а отже, мінімальні ризики, можна стверджувати 3 розгляду рейтингу країн за ступенем економічної свободи (табл. 5). Рівень економічної свободи вимірюється на основі 12 кількісних і якісних чинників, згрупованих у чотири широкі категорії: верховенство закону (права власності, цілісність уряду, судова ефективність), ефективність уряду (державні витрати, податкове навантаження, бюджетна охорона здоров'я), ефективність регулювання (свобода бізнесу, свобода праці, грошова свобода), відкриті ринки (свобода торгівлі, свобода інвестицій, фінансова свобода).

Країни - лідери рейтингу характеризуються високим рівнем науково-технічного розвитку, які використовують переваги й $є$ драйверами Індустрії 4.0. Країни-аутсайдери - це країни з високими ризиками національної економіки, які мають незадовільний стан економіки через ресурсну і фінансову залежність.

Із 10 країн - лідерів даного рейтингу три належать до нових індустріальних країн - це Сінгапур, Гонконг, Тайвань. Сплеск у розвитку для НІК почався $з$ кінця 1950-х років, вони показали винятково високі темпи економічного зростання впродовж 50-80-х років, їхні довгострокові економічні стратегії були націлені на побудову ефективної моделі капіталізму. НІК вищою мірою інтегровані в міжнародну торгівлю, для них характерний бурхливий розвиток галузей національного господарства, продукція яких призначена для експорту. Але справа не обмежувалася лише вражаючими успіхами в індустріалізації всієї економіки. За три-чотири десятиліття відбулися глибокі суспільні перетворення, здійснено революційні зрушення у сфері освіти, охорони здоров'я, розвитку інформаційно-інноваційних технологій, що доводить принципову можливість прориву окремих країн, що розвиваються, до групи розвинених держав протягом життя одного-двох поколінь. Незважаючи на великі досягнуті успіхи, НІК ще не досягли показників, що дають змогу зарахувати їх до групи розвинутих країн. Але це країни, які посідають провідні місця у світовій економіці за показниками глобальної конкуренції, інноваційного розвитку, стабільності економіки.

Багатьом здається, що Сінгапур і Гонконг країни-близнюки. Але це не так: оболонка схожа, а начинка різна, шляхи цих колишніх колоній до благополуччя виявилися протилежними. $Є$ дві країни, які в кінці минулого століття здивували світ. Обидві - колишні англійські колонії, населені на $3 / 4$ китайцями. За останні $50-60$ років вони перестрибнули 3 третього світу в перший $\mathrm{i}$ сьогодні ділять перше-друге місця в рейтингу економічно вільних країн і не перестають змагатися за звання світового фінансового центру. Становлення цих країн кардинально відрізняється. Гонконг відгукнувся на пропозицію Старої Свропи прийняти класичну модель економічного успіху, засновану на демократичних інститутах та цінностях, i в результаті трансформувався зсередини. 
А Сінгапур, звільнившись від колоніального ярма, вибрав унікальний шлях, по якому країну повів своєю жорсткою рукою Лі Куан Ю. У Сінгапурі благополуччя забезпечується жорстким законом і капіталом іноземців. А Гонконг інший. У ТОП-100 мільярдерів 2016 р. від Forbes - четверо гонконгців (на 20-му, 31-му, 58-му і 65-му місці), тоді як перший сінгапурець у списку мільярдерів зустрічається тільки на 151-му місці. Також Гонконг демонструє один із найвищих показників частки молодих бізнесменів у загальній масі - $45 \%$ проти $30 \%$ у більшості інших високорозвинених країн. В основу політики правлячої партії Сінгапуру на чолі з Лі Куан Ю були покладені такі принципи: відмова від базових громадянських і політичних прав (відсутність свободи слова і зібрань); меритократія, що виправдує необхідність панування еліти над неосвіченими масами; акцент на соціальній політиці (субсидування освіти, охорони здоров'я, житлового будівництва). Ще одна важлива особливість проєкту Лі Куан Ю - ставка на іноземний капітал. Залучені низькими податками, прозорою правовою системою, інноваційною інфраструктурою, мінімальним рівнем злочинності і корупції, іноземні компанії активно інвестували в Сінгапур. У Гонконзі політика реактивного втручання держави стимулювала розвиток приватного бізнесу та ініціативність жителів Гонконгу в усіх сферах. А демократичні цінності інсталювалися у свідомість китайців, які мігрували 3 Китаю до Гонконгу, і стали їх власними переконаннями, за які вони продовжують боротися і після повернення до складу КНР [11].

На нашу думку, для мінімізації макроекономічних ризиків та забезпечення довготривалого світового лідерства країни витрачають значні кошти на НДДКР. Фінансування НДДКР є провідним показником довгострокової економічної безпеки країни. Топ-10 країн, які в 2018 р. найбільше інвестують у дослідження і розробки: США -
476,5 млрд дол., Китай - 370,6 млрд дол., Японія - 170,5 млрд дол., Німечина -109,8 млрд дол., Південна Корея - 73,2 млрд дол., Франція 60,8 млрд дол., Індія - 48,1 млрд дол., Великобританія - 44,2 млрд дол., Бразилія - 42,1 млрд дол., Росія $-39,8$ млрд дол. [12]. У цілому, на 10 країн припадає близько $80 \%$ витрат на НДДКР усього світу. Тому можна стверджувати, що більшість із цих країн демонструють лідерські позиції у світовій економіці та ефективно управляють ризиками різного характеру 3 метою утримання стабільності своєї економіки. Інвестиції в дослідження і розробки свідчать про те, як країни будуть розвиватися в довгостроковій перспективі на основі своїх розроблених стратегій розвитку, які враховують аспект ризикових ситуацій.

Висновки. Успішне функціонування підприємства/країни/регіону в турбулентних умовах світової економіки має базуватися на ефективному управлінні ризиками. Особливу увагу в даному контексті слід приділяти проєктним ризикам. Масштаб чи географічна локація проєктів є суттєвим чинником виникнення ризиків, тому в управлінні ризиками мезо- чи мікрорівня слід ураховувати глобальні ризики. Тенденції розвитку світової економіки залежать від напрямів та активності розвитку країн-лідерів в умовах ризиковості бізнес-середовища. Виокремлення таких країн 3 усієї сукупності країн світу можливе на основі ранжування їхньої діяльності (за макроекономічними показниками) чи результатів дослідження міжнародних рейтингових агентств. У цілому більшість досліджень презентують США, СС та Китай як країни - глобальні лідери. Однак ризикологія глобального лідерства набуває нових форм та трендів. Наприклад, для одних країн суттєвим ризиком є ресурсна чи фінансова залежність, a для інших ризик кібератак $\epsilon$ визначальним. Тож для утримання світового лідерства країни мають систематично здійснювати управління ризиками з метою їх попередження та мінімізації.

\section{Список використаних джерел:}

1. The global risks report 2019. World economic forum. 2019. 14th Edition. P. 96. URL : http://www3.weforum.org/docs/ WEF_Global_Risks_Report_2019.pdf.

2. Классификация стран. Экономическая классификация стран мира. URL : http://www.ereport.ru/articles/mirecon/ classif.htm.

3. Международный валютный фонд. Информационная справка. URL : http://www.imf.org/external/np/exr/facts/rus/ glancer.pdf.

4. Члены Организации Объединенных Наций. URL : http://www.un.org/ru/member-states/index.html.

5. Группа Всемирного банка. URL : http://www.vsemirnyjbank.org/.

6. Central Intelligence Agency. URL : https://www.cia.gov/.

7. DoD Digital Modernization Strategy 6/5/2019. Department of Defense USA. P. 72.

8. COMMUNICATION FROM THE COMMISSION TO THE EUROPEAN PARLIAMENT, THE COUNCIL, THE EUROPEAN ECONOMIC AND SOCIAL COMMITTEE AND THE COMMITTEE OF THE REGIONS on the Mid-Term Review on the implementation of the Digital Single Market Strategy. A Connected Digital Single Market for All . Brussels, 10.5.2017 COM (2017) 228 final.

9. Cause for concerns? The top 10 risks to the global economy. The Economist Intelligence Unit. 2018. P. 3-4. URL : https://espas.secure.europarl.europa.eu/orbis/sites/default/files/generated/document/en/Top_10_risks_to_the_global_economy.pdf.

10. Index of Economic Freedom 2019. URL : https://www.heritage.org/index/ranking. 
11. Два шляхи з третього світу у перший: як схожі країни, Сінгапур та Гонконг, досягли успіху зовсім різними шляхами. Новое время. URL : https://nv.ua/publications/dva-puti-iz-tretego-mira-v-pervyj-kak-pohozhie-strany-singapur-igonkong-preuspeli-sovershenno-raznymi-putjami-189003.html.

12. Скільки світ витрачає на дослідження та розробки. URL : https://landlord.ua/news/skilky-svit-vytrachaiena-doslidzhennia-ta-rozrobky-infohrafika/.

\section{References:}

1. Central Intelligence Agency. (2019). URL: https://www.cia.gov/.

2. COMMUNICATION FROM THE COMMISSION TO THE EUROPEAN PARLIAMENT, THE COUNCIL, THE EUROPEAN ECONOMIC AND SOCIAL COMMITTEE AND THE COMMITTEE OF THE REGIONS on the Mid-Term Review on the implementation of the Digital Single Market Strategy . A Connected Digital Single Market for All . Brussels, 10.5.2017 COM (2017) 228 final.

3. DoD Digital Modernization Strategy 6/5/2019. (2019). Department of Defense USA. P. 72.

4. EREPORT.RU (2018). Klassifikatsiya stran. Ekonomicheskaya klassifikatsiya stran mira [Classification of countries. Economic classification of the countries of the world]. URL: http://www.ereport.ru/articles/mirecon/classif.htm.

5. International Monetary Fund. (2020). URL: http://www.imf.org/external/np/exr/facts/rus/glancer.pdf.

6. New time (2016). Dva shlyakhy z tret'oho svitu u pershyy: yak skhozhi krayiny, Sinhapur ta Honkonh, dosyahly uspikhu zovsim riznymy shlyakhamy [Two paths from the third world to the first: how similar countries, Singapore and Hong Kong, have succeeded in completely different paths]. URL: https://nv.ua/publications/dva-puti-iz-tretego-mira-v-pervyj-kak-pohozhie-strany-singapur-i-gonkong-preuspeli-sovershenno-raznymi-putjami-189003.html.

7. Skil'ky svit vytrachaye na doslidzhennya ta rozrobky [How much the world spends on research and development]. URL: https://landlord.ua/news/skilky-svit-vytrachaie-na-doslidzhennia-ta-rozrobky-infohrafika/

8. The Economist Intelligence Unit. (2018).Cause for concerns? The top 10 risks to the global economy. P. 3-4. URL: https://espas.secure.europarl.europa.eu/orbis/sites/default/files/generated/document/en/Top_10_risks_to_the_global_ economy.pdf.

9. The global risks report. (2019). World economic forum. 2019. 14th Edition. P. 96. URL: http://www3.weforum.org/docs/ WEF Global Risks Report 2019.pdf.

10. The Heritage Foundation (2020). Index of Economic Freedom 2019. URL: https://www.heritage.org/index/ranking.

11. United Nations (2020). Members of the United Nations. URL: http://www.un.org/ru/member-states/index.html.

12. World Bank Group (2020). URL: http://www.vsemirnyjbank.org/.

Dergachova Viktoriia, Manaienko Iryna National Technical University of Ukraine "Igor Sikorsky Kyiv Polytechnic Institute»

\section{RISKOLOGY: MANAGEMENT, PROJECTS, TRENDS AND PERSPECTIVES}

The scientific article is devoted to the consideration of the theoretical foundations of risk management on the one hand, and on the other - the analysis of countries-global leaders of the world economy, taking into account the risks of their operation. It is determined that project risk management has a special place in risk science. It is substantiated that geographical location is a determining factor in the risk management system. Trends and models of development of the world economy systematically lead some countries into leading positions, others - to outsiders. In this case, outsiders are those who are unable to cope with risks that can be not only economic. In doing so, risky situations undermine national security issues. Therefore, it is relevant to research countries and groups of countries that are global leaders in the global market, taking into account the risks that accompany them. The purpose of the research is to identify and substantiate the leading economies of the world economy in terms of risk, based on macroeconomic indicators of their activities and international rankings. To achieve this goal, the following methods have been used: systematization, grouping and generalization, formalization, induction and deduction, scientific abstraction, semantic analysis, etc. The information resources of leading organizations and agencies such as the IMF, the UN, the World Bank Group, the US Central Intelligence Agency, The Heritage Foundation, the World Economic Forum and The Economist Intelligence Unit were used. The research presents global risks to the world economy. The list of risks inherent in countries that hold leading positions on certain indicators is given. These indicators determine GDP per capita (leader countries - China, EU, USA), GDP per capita (leader countries - Luxembourg, Switzerland, Macau). It also identifies the leading countries in the rating of economic freedom (leader countries - Singapore, Hong Kong, New Zealand), the amount of $R \& D$ expenditure (leader countries - the United States, China, Japan) and more. It is determined that countries operate in the conditions of such risks (which are inherent to individual countries and not all leaders), such as resource or financial dependency, demographic burden, non-diversification of the economy, dependence on imported labor, etc. And the global risks include the following: price bubbles, illegal trade, uncontrolled inflation, changes in energy prices, critical unemployment, the collapse of financial institutions. The practical value of the study is to improve approaches to identify the world's leading economies, taking into account the global and specific risks of their functioning.

Key words: GDP, economy, economic freedom, leadership, ratings, risks, R\&D, projects, strategies, management.

JEL classification: A11, D81, F01. 